\title{
GROWTH AND STRUCTURAL CHANGES IN TRANSITION COUNTRIES: THE CHICKEN OR THE EGG?
}

\author{
Magdalena OLCZYK ${ }^{*}$, Aleksandra KORDALSKA (D) \\ Faculty of Management and Economics, Gdańsk University of Technology, Gdańsk, Poland \\ Received 02 October 2017; accepted 01 October 2018
}

\begin{abstract}
The objective of this study is to test empirically the relationship between structural changes (changes in gross value added and employment) and economic growth. We used a panel Granger-causality analysis based on annual data for eight transition countries, covering the period 1995-2011. The main finding is that the causality relations analysed are heterogeneous processes and are identified more often when we measure structural changes by value added than by changes in employment. Among the countries analysed, we separate a subgroup of economies with very strong bilateral causality (small countries such as Latvia, Lithuania, and Estonia), a subgroup in which no causal relationships are observed (e.g., Hungary in the case of employment), and a group with a one-directional relationship (e.g., Poland, where GDP changes cause employment changes, but not vice versa). The research results point to the necessity of taking into account different relationships, whether one- or two-directional, between growth and structural changes in government economic policy. The paper presents a verifiable methodology, which was originally used to identify the analysed relationship in transition countries.
\end{abstract}

Keywords: CEE countries, economic growth, Granger causality, industries, panel data, structural changes.

JEL classification: C23, L16, O47, O52.

\section{Introduction}

Over time, economies not only grow but also change in structure. The interconnection between economic growth and changes in the structure of an economy (often measured in terms of employment and value added) is widely accepted in economic theory, but the question of whether economic growth causes structural changes or changes in the economic structure cause aggregate growth is still unanswered (Dietrich, 2012).

So far, the literature related to economic growth and structural changes has been mostly theoretical. Based on the formulation of growth theories, it is generally hypothesized that

${ }^{\star}$ Corresponding author. E-mail: Magdalena.Olczyk@pg.edu.pl 
economic growth leads to changes in the structure of an economy, rather than the other way round. However, a few empirical studies show both that growth is important for structural changes and that structural changes are significant determinants of an economy's growth (for 13 developed OECD countries over 1970-1985, see Echevarria (1997); for seven developed OECD countries in 1960-2004, see Dietrich (2012); for India in 1988-2007, see Cortuk and Singh (2010)). These studies indicate that the causality relationships between economic growth and structural changes are very heterogeneous across the countries investigated, i.e., sometimes only a one-way relationship is observed; sometimes strong two-way relationships are seen.

In the transition countries, empirical analyses of the impact of economic growth on structural changes and vice versa are still scarce. Some evidence can be found in work by Havlik (2013), who examines the extent and patterns of structural changes and their impact on aggregate economic growth, or in work by Białowąs (2016), who assesses the same relationship in the Czech Republic, Hungary, Poland, and Slovakia. In our paper, we hold that an evaluation of this impact in this group of countries is crucial for identifying the factors in their development. Most of the transition countries that joined the European Union in 2004 achieved a GDP per capita of US\$17,000 (in constant 2005 prices) in 2011 and their rate of growth has significantly slowed in the past few years. This may indicate that these countries could be experiencing a middle-income trap, the essence of which is a long-term economic slowdown after a period of relatively rapid growth (Eichengreen, Park, \& Shin, 2012; Felipe, Kumar, \& Abdon, 2010).

The most famous victims of the average income trap have been various Latin American countries, and the best-known examples of economies that have not fallen into this trap are South Korea and Taiwan. They have managed to maintain growth after reaching the average level of income and to catch up with highly developed economies (Wheatley, 2010). The success of these Asian economies is the consequence of structural changes in their economies, so they were able to produce increasingly diverse goods, and specialization moved their economies towards the production of increasingly sophisticated goods, characterized by a high share of value added (Ohno, 2009).

The aim of this paper is therefore to use a panel Granger causality test to verify our hypothesis for the existence (or not) of a causal relationship between economic growth and structural change in selected Central and Eastern European economies, which experienced economic transformation. In these countries, the structural changes that have taken place are significant, and the dynamics of future structural changes may determine their future growth.

The paper is organized as follows. The next section outlines theoretical considerations in the definition of structural changes and the relationship between economic growth and structural changes in economic models. It includes discussion on the possible impact of structural changes on economic growth and vice versa. Section 2 begins the methodological part of the paper by introducing the methodology used to measure structural change and the panel Granger causality test. Section 3 presents the data and the results of the analysis, and the last section gives our conclusions. 


\section{Structural changes: definition and relation to economy growth}

The concepts of structure and structural changes in economics have many uses. The best source for the various ways in which the terms have been used and abused in economics is the semantic analysis by Machlup (1967), who finds almost nine different meanings of 'structure' and 'structural change' in the economic sciences.

The earliest uses of structure refer to 'different arrangements of productive activity in the economy, especially to different distributions of productive factors among various sectors of the economy, various occupations, geographic regions, types of products, etc.' (Machlup, 1967). Structure is also often described in economics as the 'composition of aggregate quantity that does not change easily', the 'distribution of inputs or output over time' or as 'a set of constant reaction coefficients which shows transformation of irregular shocks into cyclical swings' (Machlup, 1967). The term 'structure' is often found in economic literature in connection with a model, system or economy. The structure of the system mostly determines outcome-determining conditions, the structure of a model is understood as a set of known numerical constants and coefficients in econometric analysis and the structure of an economy describes the set of given and invariant conditions assumed in a theoretical analysis.

The term 'structural change' is frequently related to the concept of 'structure'. For example, Ishikawa (1987) defines structural changes as 'changes in the relative weight of significant components of the aggregative indicators of the economy, such as national product and expenditure, exports and imports, and the population and labour force'.

Machlup (1967) perceives structural changes as 'permanent (not temporary), long-term alterations of the fundamental relationships in the economy'. They are alterations in real resources, preferences or technology and do not include monetary or policy changes. Thus, he treats structural changes as a function of time. The same approach is used by Syrquin (2010), who defines structural changes as 'long-term persistent changes in the composition of an aggregate'.

However, in the economic literature, structural changes are often not described as a time function, but as a function of other economic categories, such as economic growth. In this way, Chenery, Robinson and Syrquin (1986) assert that structural changes are 'a set of changes in the composition of demand, trade, production and factor use that take place as per capita income increases'. To identify the meaning of structural changes for other economic categories, Silva and Teixeira (2008) analyse citations and papers published in Structural Change and Economic Dynamics and all the abstracts and articles on structural changes published over 40 years in other economic journals. This bibliometric analysis shows that the most popular publications related to structural change in economics pertain to the concepts of development, technological change and innovation, convergence and growth, foreign trade, employment, migration, and growth in industrial production. Among all the topics mentioned, 'growth and convergence' are the most relevant. In addition, the theoretical essay 'Structural change and economic growth', by Pasinetti (1981), is the most cited study in the literature on structural change. Therefore, this paper relies on the notion of structural change which has roots in classical economics and is strongly connected with economic growth theory. In this meaning, structural changes 'include the entire range of transformative processes that accompany economic growth, such as changes in the sectoral composition of production and 
employment, organization of the industry, financial system, income and wealth distribution, and demography' (Matsuyama, 2008).

In the economic literature, the relationship between structural change and economic growth is well recognised. Although physiocrats (Quesnay), predecessors of classical economics (Turgot), and classical economists (Smith, Ricardo, Mill, Marx) did not use the notion of structural change in their economy, they gave it a great deal of attention.

Among neoclassical economists, only Schumpeter (1934) highlighted the fact that economic growth cannot proceed without structural change, but the first significant contributions to an explanation of the relationship between structural change and growth were by Fisher (1939) and Clark (1940). Both analysed the patterns of change in sectoral employment and created the theory known as the 'three-sector hypothesis'. Fisher and Clark believed that every economy changes the sector on which it is based as it progresses along its growth path. In countries with a low national income level, economic activity focuses on raw material production; in the middle stage of a country's development, it is based on manufacturing; and when the country reaches the highest level of development, it will probably be a service economy. This leads to the conclusion that countries with a similar level of development are characterised by a similar inter-sectoral structure. The three-sector hypothesis has been the basis of many studies on structural change, understood as shifts between economic sectors (Fourastié, 1949; Kuznets, 1959; Chenery, 1960).

In the 1950s, in parallel with research on the three-sector hypothesis, interest grew in the perception of structural change as a factor of economic growth. Precursors of this trend were Rosenstein-Rodan (1943) and Nurkse (1953). They stressed sectoral differences as a requirement for balanced growth. The balanced growth approach assumes that inter-sectoral balance between economic sectors is necessary, ie, that each sector provides a market for the products of the others and in turn supplies the necessary raw materials for the development and growth of the other sectors.

However, the first comprehensive model examining the relationship between structural change and economic growth was the unbalanced growth model, developed by Baumol (1967) and Baumol, Blackman, and Wolff (1985). Baumol divides the economy into two sectors: a progressive one that uses capital and new technology and grows at a constant rate and a stagnant one that uses labour as the only input and produces services as its final output. In an economy so constructed, and due to factor mobility, structural change (defined as change in employment and expenditure) leads to a decrease in the growth rate and to potential stagnation. This is because, in the stagnant sector, production costs and prices grow (Baumol's cost disease), which results in wage increases and labour movement to this sector and consequently in a decrease in the long-term growth rate. Thus, according to Baumol, structural change has a negative impact on growth in per-capita GDP, which is expressed as a shift of employment and expenditure towards 'stagnant services' such as health care and education. Baumol's model, however, clashed with a very important neoclassical growth theory (Solow, 1956, 1957) and with a new growth theory (Lucas, 1988; Romer, 1990; Grossmann \& Helpman, 1991). All these theories focus on technical or productivity progress as engines of economic growth and treat structural change (sectoral composition) as a constant variable in their models. 
In the most recent studies, structural change again comes to the fore. In 'neo-Schumpeterian' or 'evolutionary' approaches, structural change is a useful tool for explaining technology adoption in the economy and the path-dependent nature of economic change. Two approaches can be distinguished in the recent literature. The first, called a demand-side approach, uses a homothetic utility function consistent with Engel's law (different income elasticities) to explain differences in the rate of economic growth (Echevarria, 1997; Laitner, 2000; Caselli \& Coleman, 2001; Kongsamut, Rebelo, \& Xie, 2001). The second, a supply-side approach, concentrates on explaining economic growth in terms of differences in total factor productivity growth across sectors (Ngai \& Pissarides, 2007) or of differences in factor proportions and capital deepening in the economy (Acemoglu \& Guerrieri, 2008).

In the economics literature related to the relationship between economic growth and structural change, the hypothesis that economic growth promotes structural change is dominant. Economic growth can cause changes in economic structure in two principal ways. The first one is connected with the demand side. Economic growth means income growth. In each economy, the products and services have different income elasticities - the lowest for primary products (agriculture) and the highest for the tertiary sector (services). This is why economic growth causes shifts in demand over time, ie, decreasing demand in the primary sector and increasing demand for the products of the secondary and finally the tertiary sector. Economic growth via income growth causes changes in the importance of the sectors in the economy, measured by their output share or value-added share.

The second way that economic growth causes changes in the structural composition is associated with the supply side of the economy. Sectors are characterized by different levels of labour productivity due to different levels of technical progress. If a sector has high labour productivity, it can deliver products and services at lower prices and/or the wages in this sector are higher. In both cases, due to either increasing wages or higher output, this sector becomes increasingly important in the economy. In sum, the higher the economic growth rate in a period, the higher the income in this period, and the greater the structural change in subsequent periods.

We should also ask whether an inverse relationship between growth and structural changes is possible, with structural changes affecting the economic growth rate. According to empirical studies by Stamer $(1998,1999)$ and Aiginger $(2001)$, structural change can lead to change in the economic growth rate. This situation can arise when demand increases more quickly in a sector with low productivity than in a sector with high productivity, which forces employment to shift from the secondary sector to the primary sector, eventually leading to a slower rate of economic growth. Using sectoral data for Germany in the period 1970-1993, Stamer found that economic growth has stronger influence on structural change than vice versa, while Aiginger, analysing sectoral data for 14 old European countries in the period 1985-1998, came to the conclusion that structural change has a much larger impact on economic growth. Both Stamer and Aiginger used highly disaggregated data in their research. In this paper, we divide the economies of the transition countries chosen into 21 main sectors and test the direction and strength of the relationship between structural change and economic growth in them. 


\section{Measuring structural change and Granger causality in panel data models}

The most popular measure for comparing structural changes among countries and over time is the SCI, given as:

$$
S C I_{s t}=0.5 \cdot \sum_{i=1}^{n}\left|x_{i t}-x_{i s}\right|,
$$

where $x$ is the relationship between the GVA in sector $i$ and the total GVA, or the relationship between the number of persons engaged in sector $i$ and the total number of persons engaged in the periods $t$ and $s$.

Another measure which allows structural changes to be compared is the MLI (Stamer, 1999), based on Lilien (1982), which is constructed as follows:

$$
M L I_{s t}=\sqrt{\sum_{i=1}^{n} x_{i s} x_{i t}\left(\ln \frac{x_{i t}}{x_{i s}}\right)^{2}}, x_{i s}>0, x_{i t}>0 .
$$

MLI measures the standard deviation of the sectoral growth rates between two periods, $t$ and $s$, and across countries. The shares of the sectors in the two periods are used for weighting.

In our investigation, we evaluate the causal relationship between structural change, measured by the SCI and the MLI, and GDP growth.

A paper by Granger (1969) became the starting point in the development of the methodology for testing causality. According to Granger's definition of causality, series $x$ can be said to cause series $y$ if and only if the expectation of $y$ given the history of $x$ differs from the unconditional expectation of $y$ :

$$
E\left(y \mid y_{y-k}, x_{t-k}\right) \neq E\left(y \mid y_{t-k}\right) .
$$

In other words, in the conditional distribution, lagged values of series $x$ give additional information to explain series $y$. If causality between series $y$ and series $x$ exists $(x \rightarrow y)$, current values of $y$ can be predicted better using lagged values of $x$ and $y$ than using past values of $y$ alone.

The modification of a classical Granger test to panel data test allows us not only to base it on a larger number of observations and number of degrees of freedom but also increases the test's efficiency and gives additional information from cross-sectional units to support better understanding of the form of causality.

In the panel data context, the econometric literature provides only a few ways to evaluate Granger causality, and they can be grouped into two categories (Erdil \& Yetkiner, 2009), depending on the assumptions about the parameters in the VAR model.

The first methods date back to the mid-1980s and are linked to research by Holtz-Eakin, Newey, and Rosen (1985), who assess the causal relationship between revenue and expenditure in American municipalities. The authors base their discussion on Chamberlain's (1984) solution and discuss a linear VAR model, allowing both parameters and the individual effect of Equation (4) to vary over time. Similar assumptions about the parameters are made by Hsiao (1989), Weinhold (1996, 1999), Nair-Reichert and Weinhold (2001) and Choe (2003), who employ a dynamic mixed fixed and random coefficient linear model. 
The second group of methods is based on the assumption of constancy in both autoregressive parameters and regression parameters over time and their variability across individuals. This approach is considered by Hurlin (2004), Hurlin and Venet (2001), Dumitrescu and Hurlin (2012) and Raffinot and Venet (2017). The same assumptions about the model parameters are made by Dietrich (2012) in examining the causal relationship between structural changes and economic growth in seven selected OECD countries and by Mahmood and Linden (2017) in explaining the same causal relationship in the Schengen region. This procedure takes into account the significant issue of heterogeneity among panel units in terms of causality. The procedure allows us not only to identify whether the causal relationship exists but also to specify which panel units demonstrate Granger causality and which do not. Because of merits of this approach in our investigation, we rely on Hurlin and Venet (2001) to explain causal relationships.

The Granger procedure for testing causality requires data to be stationary. This means that before the estimation is started, a test for the presence of unit roots is needed. In the case of a relatively small panel, a problem with distortion of panel unit-root tests might emerge that is connected with their power and size. With respect to the first-generation tests, in small samples, Monte Carlo simulations suggest using the Breitung (2001) test, rather than the LLC test, whose power is too low in such cases. Following Baltagi (2008), when the structure of the lags in the tested regression is chosen correctly, the IPS test (Im, Pesaran, \& Shin, 2003) also performs well. For second-generation panel unit-root tests, Monte Carlo simulations (Pesaran, 2003; Moon \& Perron, 2004) confirm the good properties of the CADF test (Pesaran, 2003) in terms of both size and power in relatively small samples. In order to evaluate Granger causality properly, all these tests are used to assess the unit roots of the data first. Our evaluation of the optimal lag length in all the tests is based on Akaike information criteria.

After the unit-root evaluation, we go to a three-step Hurlin and Venet (2001) procedure for testing causality based on Granger's definition.

Let us focus on a time-stationary VAR model adapted to a panel data context. For $T$ periods and $N$ individuals, the model is as follows:

$$
y_{i, t}=\sum_{k=1}^{p} \gamma^{k} y_{i, t-k}+\sum_{k=0}^{p} \beta_{i}^{k} x_{i, t-k}+v_{i, t},
$$

where $v_{i t}$ is the sum of individual effects $\alpha_{i}$, assumed to be fixed, and normally distributed disturbances $\varepsilon_{i t}$. Following Hurlin and Venet, we impose the following assumptions on $v_{i t}$ :

$$
\begin{gathered}
\alpha_{i} \sim \operatorname{IID}\left(0, \sigma_{\alpha}^{2}\right), \quad \varepsilon_{i t} \sim \operatorname{IID}\left(0, \sigma_{\varepsilon}^{2}\right), \\
E\left(\alpha_{i} \varepsilon_{i t}\right)=0, \\
E\left(\alpha_{i} \alpha_{j}\right)=E\left(\varepsilon_{i t} \varepsilon_{j s}\right)=0 \text { for } i \neq j \text { and } t \neq s, \\
E\left(\alpha_{i} x_{i t}\right)=E\left(\varepsilon_{i t} x_{i t}\right)=0,
\end{gathered}
$$

and make the following assumptions concerning the model coefficients:

- the autoregressive coefficients $\gamma^{k}$ and the coefficients associated with variables $x-\beta_{i}^{k}$ are constant for all lags, 
- the autoregressive coefficients $\gamma^{(k)}$ are identical for all individuals, but the regression coefficient slopes $\beta_{i}^{k}$ may have an individual dimension.

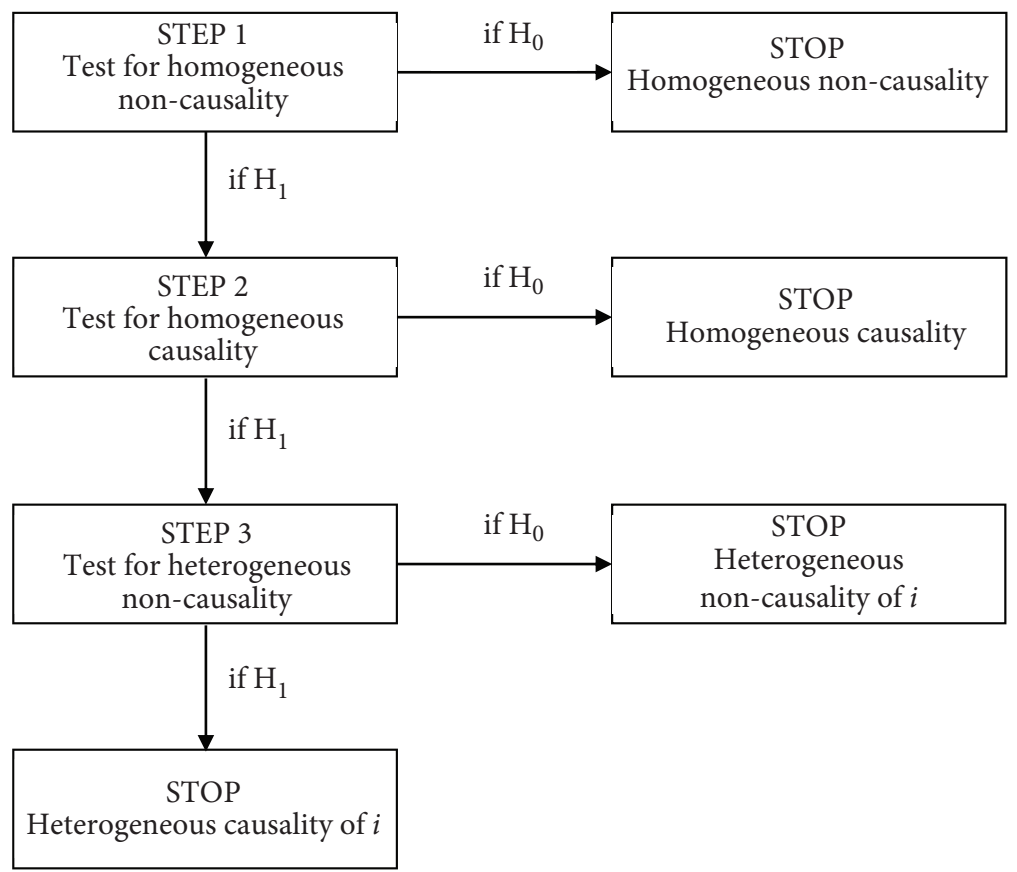

Figure 1. Test for Granger causality in panel data models

As mentioned above, in panel data models we expect heterogeneity between individuals for two reasons. First, we can observe natural permanent cross-sectional differences between individuals. This kind of heterogeneity is taken into consideration by introducing individualfixed parameters $\alpha_{i}$. Second, heterogeneous coefficients are associated with the exogenous variable $x$. In a group of individuals, we can find a subgroup of countries in which causality between $x$ and $y$ exists $\left(\beta_{i}^{k} \neq 0\right)$ and a subgroup in which no causal relationship is observed $\left(\beta_{i}^{k}=0\right)$. The details of the procedure are shown in Figure 1 and Table 1.

Table 1. Hypotheses and test statistics in Granger causality tests for panel data models

\begin{tabular}{|l|l|}
\hline \multicolumn{1}{|c|}{ Hypotheses } & \multicolumn{1}{|c|}{ Test statistics } \\
\hline \multicolumn{2}{|c|}{ Step 1} \\
\hline $\begin{array}{l}H_{0}: \beta_{i}^{k}=0 \forall i=1, \ldots, N \forall k=1, \ldots, p \\
H_{1}: \exists(i, k) \beta_{i}^{k} \neq 0\end{array}$ & $F_{H N C}=\frac{\left(R S S_{2}-R S S_{1}\right) / N p}{R S S_{1} /(N T-N(1+p)-p)}$ \\
\hline \multicolumn{2}{|c|}{ Step 2} \\
\hline $\begin{array}{l}H_{0}: \forall k=1, \ldots, p / \beta_{i}^{k}=\beta^{k} \quad \forall i=1, \ldots, N \\
H_{1}: \exists k \in[1, p], \exists(i, j) \in[1, N] / \beta_{i}^{k} \neq \beta_{j}^{k}\end{array}$ & $F_{H C}=\frac{\left(R S S_{3}-R S S_{1}\right) /(N-1) p}{R S S_{1} /(N T-N(1+p)-p)}$ \\
\hline
\end{tabular}


End of Table 1

\begin{tabular}{|l|l|}
\hline \multicolumn{1}{|c|}{ Hypotheses } & Test statistics \\
\hline \multicolumn{2}{|c|}{ Step 3 } \\
\hline$H_{0}: \exists i \in[1, N] / \forall k \in[1, p] \beta_{i}^{k}=0$ & $F_{H E N C}=\frac{\left(R S S_{2, i}-R S S_{1}\right) / p}{R S S_{1} /(N T-N(1+2 p)+p)}$ \\
$H_{1}: \forall i=1, \ldots, N \exists k \in[1, p] / \beta_{i}^{k} \neq 0$ & \\
\hline
\end{tabular}

In the first step of the procedure, we test our homogeneous non-causality hypothesis, which posits the absence of a causal relationship for all individuals. Based on unrestricted and restricted residual sum of squares of regression (4), $\mathrm{RSS}_{1}$ and $\mathrm{RSS}_{2}$ respectively, we check whether the coefficients $\beta_{i}^{k}$ for all panel groups $i$ and all lags $k$ are statistically significant. Testing the slope coefficients for all $i$ at once and all $k$ means that we treat the panel as homogeneous. A lack of significance means that a causality relationship for all the individuals does not exist, but if we reject the hypothesis, then the second step of the procedure can be taken.

The second step tests for homogeneous causality (HC) and questions whether the slope coefficients for all individuals are identical. Computing $\mathrm{RSS}_{3}$ - the restricted residual sum of squares under the assumption that $\beta_{1}^{k}=\beta_{2}^{k}=\ldots=\beta_{N}^{k}=\beta^{k}$ - leads to the specification of Wald statistics referred to as $F_{H C}$. Rejection of the HC hypothesis implies differences among $\beta_{i}^{k}$ and lets us treat the panel as heterogeneous, where, for at least one or more panel members, $x$ does not Granger cause $y$.

The last step tests the HEN hypothesis. The test is conducted for each panel unit separately. RSS 2 is the restricted residual sum of squares, where $\beta_{i}^{k}$ for particular panel member $i$ and all its lags are nullified or removed from the model. Our decision about rejection of the HEN hypothesis results in identification of a subgroup of individuals who demonstrate a causality relationship and a subgroup that does not.

The panel database that we use in explaining the causal relationship is constructed for eight economies and contains macroeconomic data only. Additionally, Hurlin and Venet (2001) assume that individual effects for panel members should be fixed. In such cases, the appropriate estimation procedure is an LSDV estimation (Baltagi, 2008).

However, the model that constitutes the essence of their approach contains lagged dependent explanatory variables. This introduces a crucial question about the quality of LSDV estimation results. The discussion linked to the dynamic panel data models and estimator properties focuses mainly on samples where $\mathrm{N}>>\mathrm{T}-\mathrm{ie}$, for micropanels rather than for macropanels. As Nickell (1981) claims, in such samples the biasness and inconsistency of the LSDV estimator appear, however, the longer the time dimension, the greater the consistency in the LSDV estimator. Well-known solutions to correct that bias include Arellano and Bond's (1991) GMM estimator and its extensions by Arellano and Bover (1995) and Blundell and Bond (1998). Because our sample size in terms of the number of individuals is not large enough, as mentioned earlier, the methods described above and assigned for dynamic panels are not appropriate in our case and cannot be used.

Based on a comparison of LSDV and GMM variance, which is usually smaller for LSDV, another approach is introduced by Kiviet $(1995,1999)$. He evaluates the biasness of LSDV, 
which is $O\left(N^{-1} T^{-2}\right)$, subtracts it from the original estimator and proposes the bias-corrected LSDV estimator for small N, which outperforms the GMM in terms of bias and RMSE. Kiviet's proposal is designed for the first order of autoregression only. However, taking into consideration the properties of the LSDVC estimator, we decided to use it to evaluate causality between structural change and economic growth ${ }^{1}$.

On the other hand, Islam (2001) compares different estimators for a dynamic panel growth-convergence equation based on a small sample and states that the LSDV estimator 'proves to be a relatively superior estimator for the problem' although $T$ is small and that small-sample properties of estimators may depend on the problem analysed and data considered. The LSDV estimator is also used by Dietrich (2012) to assess the causality of structural changes vs. economic growth with the aid of a VAR model. Moreover, using a Monte Carlo simulation, Beck and Katz (2009) show that, for time-series-cross-section data, an LSDV estimator with lagged dependent explanatory variables performs about as well as Kiviet's LSDVC estimator.

Taking into account all the foregoing, we decided to use both LSDV and LSDVC estimators, in which the results from LSDVC are limited to only one lag.

\section{Data and empirical results}

The Granger test of causal relationships described in the previous section is conducted to examine a panel of eight Central and Eastern European transition countries which joined the European Union in 2004 - the Czech Republic, Estonia, Hungary, Lithuania, Latvia, Poland, Slovakia and Slovenia - using annual data from 1995 to 2011.

To obtain a higher level of disaggregation, we divide the economy into 21 branches, according to the NACE revision 2. The sectoral data for GVA, the number of persons employed $^{2}$ and the GDP growth rate are taken from the Eurostat database and the WIOD database (Timmer, Dietzenbacher, Los, Stehrer, \& de Vries, 2015). The measures of structural changes for GVA and EMP are calculated on the basis of the SCI and the MLI. Both indicators are presented in Appendix 1, and the SCI for GVA, the SCI for employment and GDP growth are presented in Appendix 2.

For the purpose of evaluating the presence of a unit root, we use the three-panel unit-root tests in the previous section: the Breitung test, the IPS test and the CADF test. The results of the tests are presented in Table 2.

For all the panel series mentioned, the unit-root tests reject the null hypothesis that the series contains a unit root. Both the structural change measures - the SCI and the MLI for GVA and employment - and the GDP growth rate are stationary and can be used in further calculations.

\footnotetext{
${ }^{1}$ In our calculations, we use a Stata routine -xtlsdvc- developed by Bruno (2005), which also corrects the bias for models with only one lag of a dependent variable.

${ }^{2}$ In Latvia, Lithuania and Poland, and for employment only, we were forced to use NACE rev. 1.1, because of a lack of corresponding data at the beginning of the period analysed. It also forced us to limit period of our analysis to 1995-2011.
} 
Table 2. Panel unit-root tests

\begin{tabular}{|l|c|c|c|}
\hline & Breitung test & IPS test & CADF test \\
\hline$\Delta G D P$ & $-3.6183^{* * *}$ & $-2.0659^{* *}$ & $-1.4000^{*}$ \\
\hline SCI_GVA & $-4.2872^{* * *}$ & $-5.3029^{* * *}$ & $-4.5160^{* * *}$ \\
\hline SCI_EMP & $-3.8836^{* * *}$ & $-7.7696^{* * *}$ & $-6.8620^{* * *}$ \\
\hline MLI_GVA & $-4.7322^{* * *}$ & $-5.5160^{* * *}$ & $-5.3100^{* * *}$ \\
\hline MLI_EMP & $-4.6155^{* * *}$ & $-6.3933^{* * *}$ & $-7.1620^{* * *}$ \\
\hline
\end{tabular}

Note: significant at ${ }^{*} 0.1 \%,{ }^{* *} 0.05 \%,{ }^{* *} 0.01 \%$

Based on stationary panel data, we estimate the following equations:

$$
\begin{aligned}
& S C I_{i t}=\sum_{k=1}^{p} \gamma^{k} S C I_{i, t-k}+\sum_{k=0}^{p} \beta_{i}^{k} \Delta G D P_{i, t-k}+v_{i t}, \\
& \Delta G D P_{i t}=\sum_{k=1}^{p} \gamma^{k} \Delta G D P_{i, t-k}+\sum_{k=0}^{p} \beta_{i}^{k} S C I_{i, t-k}+v_{i t}
\end{aligned}
$$

and

$$
\begin{aligned}
& M L I_{i t}=\sum_{k=1}^{p} \gamma^{k} M L I_{i, t-k}+\sum_{k=0}^{p} \beta_{i}^{k} \Delta G D P_{i, t-k}+v_{i t}, \\
& \Delta G D P_{i t}=\sum_{k=1}^{p} \gamma^{k} \Delta G D P_{i, t-k}+\sum_{k=0}^{p} \beta_{i}^{k} M L I_{i, t-k}+v_{i t} .
\end{aligned}
$$

Taking into account the literature review for dynamic panel data models in the previous section, we use two estimators - the LSDV estimator and the bias-corrected LSDV by Kiviet (1999). Due to the small size of our sample in terms of T, we analyse the models described above with the number of lags limited to three for LSDV and one for LSDVC estimation. In both models, we follow Hurlin and Venet's (2001) assumption on unit-specific fixed effects.

Tables 3 and 4 present the results for the HNC hypothesis. All the test statistics are significant. Regardless of the estimator, for all lags and both structural change indices for GVA and EMP, the HNC hypothesis is strongly rejected. This means that structural change measured by GVA and the number of people employed Granger cause GDP changes and vice versa. We confirm a causal bi-directional relationship between the phenomena analysed in all the countries.

Table 3. Results on homogeneous non-causality for GVA

\begin{tabular}{|c|c|c|c|c|c|c|c|c|}
\hline \multirow{2}{*}{ Lag } & \multicolumn{3}{|c|}{ Structural changes in GVA $\rightarrow \Delta \mathrm{GDP}$} & \multicolumn{3}{c|}{$\Delta \mathrm{GDP} \rightarrow$ structural changes in GVA } \\
\cline { 2 - 9 } & \multicolumn{2}{|c|}{ SCI } & \multicolumn{2}{c|}{ MLI } & \multicolumn{2}{c|}{ SCI } & \multicolumn{2}{c|}{ MLI } \\
\cline { 2 - 9 } & LSDV & LSDVC & LSDV & LSDVC & LSDV & LSDVC & LSDV & LSDVC \\
\hline 1 & $13.5794^{* * *}$ & $17.9294^{* * *}$ & $11.8914^{* * *}$ & $16.7204^{* * *}$ & $14.2928^{* * *}$ & $13.2201^{* * *}$ & $13.8217^{* * *}$ & $12.7672^{* * *}$ \\
\hline 2 & $6.3117^{* * *}$ & - & $5.5971^{* * *}$ & - & $8.6568^{* * *}$ & - & $8.5464^{* * *}$ & - \\
\hline 3 & $6.6828^{* * *}$ & - & $6.0752^{* * *}$ & - & $9.8994^{* * *}$ & - & $10.8811^{* * *}$ & - \\
\hline
\end{tabular}

Note: ${ }^{\star \star \star}$ significant at $0.01 \%$ 
Table 4. Results on homogeneous non-causality for employment

\begin{tabular}{|c|c|c|c|c|c|c|c|c|}
\hline \multirow{3}{*}{ Lag } & \multicolumn{4}{|c|}{ Structural changes in EMP $\rightarrow \Delta \mathrm{GDP}$} & \multicolumn{4}{|c|}{$\Delta \mathrm{GDP} \rightarrow$ structural changes in EMP } \\
\hline & \multicolumn{2}{|c|}{ SCI } & \multicolumn{2}{|c|}{ MLI } & \multicolumn{2}{|c|}{ SCI } & \multicolumn{2}{|c|}{ MLI } \\
\hline & LSDV & LSDVC & LSDV & LSDVC & LSDV & LSDVC & LSDV & LSDVC \\
\hline 1 & $3.9365^{\star * *}$ & $14.9287^{\star * *}$ & $4.2787^{\star * *}$ & $16.6177^{* * *}$ & $8.9305^{* * *}$ & $8.2732^{\star * *}$ & $8.4625^{* * *}$ & $7.8181^{* * *}$ \\
\hline 2 & $3.3721^{\star * *}$ & - & $4.389^{* * *}$ & - & $5.0197^{\star * *}$ & - & $4.8434^{\star * *}$ & - \\
\hline 3 & $3.3037^{* * *}$ & - & $3.6046^{\star * *}$ & - & $3.8152^{* * *}$ & - & $3.6487^{\star * *}$ & - \\
\hline
\end{tabular}

Note: ${ }^{* *}$ significant at $0.01 \%$

The next step is to determine whether the relationship investigated is homogeneous. The results from testing the HC hypothesis are shown in Tables 5 and 6. We cannot see the influence of structural change in GVA on the GDP growth rate for only two lags and the influence of structural changes in EMP on $\triangle \mathrm{GDP}$ only for the first lag and the SCI. For the rest, the HC hypothesis can be rejected, and we can confirm that structural change causes GDP growth and GDP growth causes structural change in at least one economy. This indicates that the causality process is not homogeneous.

Table 5. Results on homogeneous causality for GVA

\begin{tabular}{|c|c|c|c|c|c|c|c|c|}
\hline \multirow{3}{*}{ Lag } & \multicolumn{4}{|c|}{ Structural changes in GVA $\rightarrow \Delta \mathrm{GDP}$} & \multicolumn{4}{|c|}{$\Delta \mathrm{GDP} \rightarrow$ structural changes in GVA } \\
\hline & \multicolumn{2}{|c|}{ SCI } & \multicolumn{2}{|c|}{ MLI } & \multicolumn{2}{|c|}{ SCI } & \multicolumn{2}{|c|}{ MLI } \\
\hline & LSDV & LSDVC & LSDV & LSDVC & LSDV & LSDVC & LSDV & LSDVC \\
\hline 1 & $3.4108^{* * *}$ & $4.0696^{\star * *}$ & $2.8416^{* * *}$ & $3.3825^{\star * *}$ & $2.3809^{\star *}$ & $2.1439^{\star *}$ & $2.4047^{\star *}$ & $2.1598^{\star *}$ \\
\hline 2 & 1.4914 & - & 1.2096 & - & $1.5889^{\star}$ & - & $1.7914^{\star}$ & - \\
\hline 3 & $2.4472^{\star * *}$ & - & $1.8568^{\star * *}$ & - & $2.9145^{\star * *}$ & - & $3.1562^{* * *}$ & - \\
\hline
\end{tabular}

Note: significant at ${ }^{*} 0.1 \%,{ }^{* *} 0.05 \%,{ }^{* *} 0.01 \%$

Table 6. Results on homogeneous causality for employment

\begin{tabular}{|c|c|c|c|c|c|c|c|c|}
\hline \multirow{2}{*}{ Lag } & \multicolumn{3}{|c|}{ Structural changes in EMP $\rightarrow \Delta$ GDP } & \multicolumn{3}{c|}{$\Delta$ GDP $\rightarrow$ structural changes in EMP } \\
\cline { 2 - 9 } & \multicolumn{2}{|c|}{ SCI } & \multicolumn{2}{|c|}{ MLI } & \multicolumn{2}{c|}{ SCI } & \multicolumn{2}{c|}{ MLI } \\
\cline { 2 - 9 } & LSDV & LSDVC & LSDV & LSDVC & LSDV & LSDVC & LSDV & LSDVC \\
\hline 1 & 1.7105 & $3.5759^{* * *}$ & $2.0399^{* *}$ & $5.1381^{* * *}$ & $4.3629^{* * *}$ & $3.9961^{\star * *}$ & $4.2183^{* * *}$ & $3.8631^{\star * *}$ \\
\hline 2 & $1.5444^{*}$ & - & $2.3812^{* * *}$ & - & $2.6073^{* * *}$ & - & $2.4214^{* * *}$ & - \\
\hline 3 & $2.0036^{* * *}$ & - & $2.2204^{* * *}$ & - & $2.1624^{* * *}$ & - & $1.9309^{* *}$ & - \\
\hline
\end{tabular}

Note: significant at ${ }^{* *} 0.05 \%,{ }^{* *} 0.01 \%$

Rejection of the HC hypothesis leads us to ask in which countries Granger causality is observed. The HENC hypothesis needs to be tested. The results are presented in Tables 7 and 8 . 
In five countries - Estonia, Latvia, Lithuania, Slovakia and Slovenia - the HENC hypothesis is strongly rejected for all lags and both relationships. In these countries a bi-directional causal relationship is seen. In Hungary and the Czech Republic, the relationship analysed is not so strong as in those four countries and depends on the lag length. Poland is the only country where we do not find any relationship: structural change does not cause GDP change, nor does GDP change cause structural change.

Table 7. Results on heterogeneous non-causality for GVA

\begin{tabular}{|c|c|c|c|c|c|c|c|c|c|}
\hline \multirow{3}{*}{$\begin{array}{c}\text { Coun- } \\
\text { try }\end{array}$} & \multirow{3}{*}{ Lag } & \multicolumn{4}{|c|}{ Structural changes in GVA $\rightarrow \Delta \mathrm{GDP}$} & \multicolumn{4}{|c|}{$\Delta \mathrm{GDP} \rightarrow$ structural changes in GVA } \\
\hline & & \multicolumn{2}{|c|}{ SCI } & \multicolumn{2}{|c|}{ MLI } & \multicolumn{2}{|c|}{ SCI } & \multicolumn{2}{|c|}{ MLI } \\
\hline & & LSDV & LSDVC & LSDV & LSDVC & LSDV & LSDVC & LSDV & LSDVC \\
\hline \multirow{3}{*}{$\begin{array}{c}\text { Czech } \\
\text { Repub- } \\
\text { lic }\end{array}$} & 1 & $7.181^{* * *}$ & $15.743^{\star * *}$ & $6.857^{\star \star *}$ & $16.326^{* * *}$ & $6.736^{\star *}$ & $6.172^{\star \star}$ & $5.735^{\star \star}$ & $5.256^{\star *}$ \\
\hline & 2 & $2.910^{*}$ & - & $2.687^{\star}$ & - & $3.176^{\star *}$ & - & $2.681^{*}$ & - \\
\hline & 3 & $2.201^{\star}$ & - & $2.156^{\star}$ & - & $3.627^{\star \star}$ & - & $2.890^{\star \star}$ & - \\
\hline \multirow[t]{3}{*}{ Estonia } & 1 & $41.563^{* * *}$ & $36.526^{\star * *}$ & $32.864^{\star * *}$ & $27.561^{* * *}$ & $26.834^{\star * *}$ & $24.962^{\star * *}$ & $14.460^{* * *}$ & $15.121^{\star * *}$ \\
\hline & 2 & $15.329^{* * *}$ & - & $11.243^{* * *}$ & - & $14.638^{* * *}$ & - & $9.079^{* * *}$ & - \\
\hline & 3 & $14.764^{* * *}$ & - & $13.541^{\star * *}$ & - & $14.454^{\star * *}$ & - & $10.133^{* * *}$ & - \\
\hline \multirow{3}{*}{$\begin{array}{c}\text { Hun- } \\
\text { gary }\end{array}$} & 1 & $2.810^{*}$ & 2.569 & 2.63 & $3.384^{*}$ & $3.167^{\star \star}$ & $2.882^{\star}$ & $3.841^{\star \star}$ & $4.222^{\star \star}$ \\
\hline & 2 & $2.576^{\star}$ & - & 2.355 & - & 1.636 & - & 2.347 & - \\
\hline & 3 & $3.071^{\star *}$ & - & $2.736^{\star *}$ & - & 2.078 & - & 2.434 & - \\
\hline \multirow[t]{3}{*}{\begin{tabular}{|l|} 
Latvia \\
\end{tabular}} & 1 & $20.435^{\star * *}$ & $45.665^{* * *}$ & $15.970^{\star * *}$ & $47.682^{\star * *}$ & $16.671^{* * *}$ & $15.419^{\star * *}$ & $15.746^{* * *}$ & $16.682^{* * *}$ \\
\hline & 2 & $8.760^{* * *}$ & - & $6.949^{\star * *}$ & - & $11.614^{* * *}$ & - & $11.652^{* * *}$ & - \\
\hline & 3 & $12.162^{* * *}$ & - & $10.532^{\text {t**}}$ & - & $13.961^{* * *}$ & - & $15.803^{\star * *}$ & - \\
\hline \multirow{3}{*}{\begin{tabular}{|c|}
$\begin{array}{c}\text { Lithu- } \\
\text { ania }\end{array}$ \\
\end{tabular}} & 1 & $26.162^{\star * \star}$ & $29.308^{* * *}$ & $24.624^{\star * *}$ & $26.124^{* * *}$ & $35.095^{* * *}$ & $32.624^{\star * *}$ & $28.530^{* * *}$ & $28.478^{* * *}$ \\
\hline & 2 & $12.392^{* * *}$ & - & $12 \cdot 110^{\star * *}$ & - & $19.667^{* * *}$ & - & $16.853^{* * *}$ & - \\
\hline & 3 & $11.208^{\star * *}$ & - & $10.573^{\star \star * *}$ & - & $18.495^{\star * *}$ & - & $17.480^{* * *}$ & - \\
\hline \multirow[t]{3}{*}{ Poland } & 1 & 0.624 & 0.562 & 0.521 & 0.474 & 0.638 & 0.502 & 0.719 & 0.573 \\
\hline & 2 & 0.47 & - & 0.449 & - & 0.501 & - & 0.724 & - \\
\hline & 3 & 0.541 & - & 0.723 & - & 0.883 & - & 1.283 & - \\
\hline \multirow{3}{*}{$\begin{array}{c}\text { Slova- } \\
\text { kia }\end{array}$} & 1 & $7.117^{\star * *}$ & $8.112^{* * *}$ & $7.161^{\star * *}$ & $8.873^{\star * *}$ & $20.179^{\star * *}$ & $18.556^{\star * *}$ & $25.659^{\star * *}$ & $23.760^{* * *}$ \\
\hline & 2 & $4.067^{\star \star}$ & - & $4.500^{\star \star}$ & - & $11.558^{\star * *}$ & - & $16.843^{* * *}$ & - \\
\hline & 3 & $4.176^{* * *}$ & - & $4.184^{\star * \star}$ & - & $12.557^{* * *}$ & - & $18.55^{* * *}$ & - \\
\hline \multirow{3}{*}{$\begin{array}{c}\text { Slove- } \\
\text { nia }\end{array}$} & 1 & $9.048^{\star * *}$ & $13.561^{* * *}$ & $9.944^{* * *}$ & $17.189^{* * *}$ & $5.001^{\star *}$ & $4.579^{\star *}$ & $7.490^{* * *}$ & $7.880^{\star * *}$ \\
\hline & 2 & $5.047^{\star * *}$ & - & $5.062^{\star * *}$ & - & $3.153^{* *}$ & - & $5.259^{* * *}$ & - \\
\hline & 3 & $3.908^{\star *}$ & - & $4.042^{* * *}$ & - & $3.160^{\star \star}$ & - & $5.328^{\star * *}$ & - \\
\hline
\end{tabular}

Note: significant at ${ }^{\star} 0.1 \%,{ }^{\star \star} 0.05 \%,{ }^{\star *} 0.01 \%$

In two countries - Latvia and Lithuania - irrespective of the lag length chosen, we find a strong bi-directional causality relation between structural change in employment and economic growth. Unlike in Table 7, in Poland the direction of strong causality is only from GDP 
growth to employment. In the Czech Republic and Slovakia, the opposite direction is found (but mainly when we use MLI), and if only one lag is included, we can see that growth causes structural change in employment. In Estonia, we reject the HNC hypothesis for employment vs. growth when two or three lags are included (LSDV) and for one lag (LSDVC). The inverse relationship, in which economic growth causes structural change in employment, is confirmed for a lag length of only one and two. In the remaining countries - Hungary and Slovenia - the test statistics either never exceed their critical values or are only slightly significant at $10 \%$, and therefore we claim that employment neither causes growth nor is caused by it.

Table 8. Results on heterogeneous non-causality for employment

\begin{tabular}{|c|c|c|c|c|c|c|c|c|c|}
\hline \multirow{3}{*}{$\begin{array}{c}\text { Coun- } \\
\text { try }\end{array}$} & \multirow{3}{*}{ Lag } & \multicolumn{4}{|c|}{ Structural changes in EMP $\rightarrow \Delta \mathrm{GDP}$} & \multicolumn{4}{|c|}{$\Delta \mathrm{GDP} \rightarrow$ structural changes in EMP } \\
\hline & & \multicolumn{2}{|c|}{ SCI } & \multicolumn{2}{|c|}{ MLI } & \multicolumn{2}{|c|}{ SCI } & \multicolumn{2}{|c|}{ MLI } \\
\hline & & LSDV & LSDVC & LSDV & LSDVC & LSDV & LSDVC & LSDV & LSDVC \\
\hline \multirow{3}{*}{$\begin{array}{l}\text { Czech } \\
\text { Repub- } \\
\text { lic }\end{array}$} & 1 & $3.882^{*}$ & $7.676^{* * *}$ & $5.248^{\star *}$ & $12.694^{* * *}$ & 1.510 & 1.349 & $2.960^{*}$ & 2.713 \\
\hline & 2 & $2.596^{*}$ & - & $3.948^{* *}$ & - & 0.436 & - & 1.316 & - \\
\hline & 3 & 1.899 & - & $2.318^{\star}$ & - & 0.372 & - & 0.965 & - \\
\hline \multirow{3}{*}{ Estonia } & 1 & 1.065 & $9.023^{* * *}$ & 1.738 & $12.887^{\star * *}$ & $3.225^{\star}$ & $2.915^{\star}$ & $3.667^{\star}$ & $3.326^{\star}$ \\
\hline & 2 & $5.341^{\star * *}$ & - & $9.449^{\star * *}$ & - & $2.540^{*}$ & - & $2.522^{*}$ & - \\
\hline & 3 & $7.693^{\star * *}$ & - & $8.019^{* * *}$ & - & 1.253 & - & 1.291 & - \\
\hline \multirow{3}{*}{$\begin{array}{l}\text { Hun- } \\
\text { gary }\end{array}$} & 1 & 1.315 & $2.869^{\star}$ & 0.793 & $3.431^{\star}$ & 1.304 & 1.168 & 0.693 & 0.603 \\
\hline & 2 & 1.279 & - & 0.756 & - & 0.661 & - & 0.341 & - \\
\hline & 3 & 0.930 & - & 0.582 & - & 0.605 & - & 0.319 & - \\
\hline \multirow{3}{*}{ Latvia } & 1 & $17.410^{\star * *}$ & $37.703^{* * *}$ & $13.591^{\star * *}$ & $41.806^{\star * *}$ & $48.246^{* * *}$ & $45.087^{\star * *}$ & $32.932^{\star * *}$ & $30.695^{* * *}$ \\
\hline & 2 & $13.599^{* * *}$ & - & $13.521^{* * *}$ & - & $25.405^{\star * *}$ & - & $18.001^{\star * *}$ & - \\
\hline & 3 & $9.389^{* * *}$ & - & $8.582^{\star * *}$ & - & $15.900^{* * *}$ & - & $11.816^{\star * *}$ & - \\
\hline \multirow{3}{*}{$\begin{array}{l}\text { Lithu- } \\
\text { ania }\end{array}$} & 1 & $4.806^{\star *}$ & $21.974^{\star * *}$ & $7.319^{* * *}$ & $20.927^{\star \star *}$ & $9.817^{\star * *}$ & $9.117^{\star * *}$ & $9.108^{* * *}$ & $8.436^{\star * *}$ \\
\hline & 2 & $4.120^{\star *}$ & - & $5.455^{\star * *}$ & - & $4.295^{\star *}$ & - & $4.879^{\star * *}$ & - \\
\hline & 3 & $3.228^{\star *}$ & - & $3.224^{* *}$ & - & $2.406^{*}$ & - & $3.532^{\star \star}$ & - \\
\hline \multirow{3}{*}{ Poland } & 1 & 1.090 & $3.586^{*}$ & 1.091 & 2.629 & $18.703^{* * *}$ & $17.307^{\star * *}$ & $26.534^{\star * * *}$ & $24.655^{\star * *}$ \\
\hline & 2 & 0.686 & - & 0.715 & - & $10.180^{\star * *}$ & - & $14.187^{\star * *}$ & - \\
\hline & 3 & 0.464 & - & 0.476 & - & $7.036^{\star * *}$ & - & $9.055^{\star * *}$ & - \\
\hline \multirow{3}{*}{$\begin{array}{c}\text { Slova- } \\
\text { kia }\end{array}$} & 1 & $3.788^{*}$ & $3.771^{*}$ & $6.225^{\star *}$ & $8.571^{\star * *}$ & 1.328 & $2.055^{\star}$ & $2.852^{\star}$ & 2.628 \\
\hline & 2 & 1.195 & - & $2.720^{\star}$ & - & 0.911 & - & 1.549 & - \\
\hline & 3 & 1.497 & - & $3.474^{\star \star}$ & - & 0.730 & - & 1.086 & - \\
\hline \multirow{3}{*}{$\begin{array}{c}\text { Slove- } \\
\text { nia }\end{array}$} & 1 & 1.514 & $2.814^{\star}$ & 2.717 & $3.154^{\star}$ & 0.381 & $3.163^{*}$ & 1.420 & 1.281 \\
\hline & 2 & 0.134 & - & $2.852^{*}$ & - & 0.338 & - & 0.846 & - \\
\hline & 3 & 1.628 & - & 1.971 & - & 0.671 & - & 0.983 & - \\
\hline
\end{tabular}

Note: significant at ${ }^{\star} 0.1 \%,{ }^{* *} 0.05 \%,{ }^{* *} 0.01 \%$ 
In sum, we found that a causal relationship between economic growth and structural change occurs more frequently when we measure structural change by value added than by changes in employment. Economic theories provide an explanation why this is the case. GVA changes are closely related to changes in productivity, which can be defined as the ratio of value added in the economy to inputs used in production and is considered the main driver of GDP growth in many countries (OECD, 2016). The question is: Why are changes in GDP not strongly connected with changes in employment?

Economic theories indicate that in various countries employment reacts to economic growth in different ways at different times. First, the literature discusses Okun's law, which shows the relationship between economic growth and unemployment (reversal of employment). According to Okun's law, the ratio of economic growth to falling unemployment (or employment growth) is not one to one - ie, a $1 \%$ increase in the rate of economic growth above the trend or potential economic growth leads to growth in employment of only $0.3 \%$ (Ball, Jalles, \& Loungani, 2015). The most recent empirical analyses of Okun's coefficient for eight countries in Eastern Europe (Belarus, Bulgaria, Czech Republic, Romania, Poland, Ukraine, Hungary and Slovakia) between 1992-2014 shows that a 1\% rise in GDP will make unemployment fall/increase by only 0.08\% (Soylu, Çakmak, \& Okur, 2018).

Second, economic growth depends not only on changes in the size of employment and the quality of human capital but also on changes in capital formation and its quality and, above all, on their productivity. When the rate of labour productivity growth is high, economic growth is possible with a zero or negative employment growth rate. This phenomenon in the literature, known as 'jobless growth', applies mainly to countries that have undergone transformation or have inflexible labour markets (Semmler, Madrick, \& Khemraj, 2006). The scale of dependence of economic growth on employment is also determined by the relationship between labour costs and capital costs. The higher the labour costs, the stronger the acceleration of economic growth that results in an increase in labour productivity, not the level of employment. Therefore, in some countries in the initial period of economic recovery, the level of employment does not change.

Third, in economics we find many other concepts showing that economic growth can positively or negatively affect unemployment/employment or vice versa. The most widely known is the Pissarides model (1990), in which the rate of technical progress directly affects the labour market through the capitalisation effect (high productivity growth increases the expected profits and provides incentives to create new jobs). In turn, Aghion and Howitt (1998) state that faster productivity growth, embodied in industrial innovation, generates job destruction, rather than job creation (the creative destruction effect). These exemplary models confirm the lack of consistency in economic theories over the direction and strength of the relationship between employment and economic growth.

\section{Conclusions}

This article has examined whether a causal relationship exists among important economic processes. We explored whether economic growth causes structural change or it is the other way round and have used the Granger causality test, extended to panel data. We used two 
different measures of structural change - the SCI and the MLI - to calculate changes in GVA and employment. We found that, in general, causality in our sample of eight transition EU countries is heterogeneous.

We found that a causal relationship occurs between economic growth and structural change more frequently when we measure structural change by GVA than by changes in employment. The exception is Poland, which has the largest economy among the countries surveyed, for which, in the case of GVA, we found no significant impact on economic growth and vice versa, but we did identify a very strong one-way causal relationship between economic growth and employment.

In very small countries, such as Latvia, Lithuania and Estonia, bidirectional causality was observed, irrespective of whether structural change is measured in terms of employment or GVA.

Of course, the results require more detailed explanations of the channel through which economic growth affects structural change and vice versa in the major sectors of the economy.

Due to the small size of the time series, we used a year-on-year comparison, in which temporary factors can strongly influence structural measures in some cases, and thus they can hide the real long-term changes. For this reason, we recommend re-estimating the relationships analysed when a longer time series is available and the data can be divided into sub-periods.

This study should be regarded as preliminary. Further analyses are needed. It would be worthwhile to quantify the strength of the observed causal relationship and check the hypothesis about the potential substitution of the growth of employment by the increase in GVA in economic growth in the transition countries. Additionally, it would be beneficial to identify which factors mostly determine the causal relationship between changes in GDP and in employment/value added.

\section{References}

Acemoglu, D., \& Guerrieri, V. (2008). Capital deepening and nonbalanced economic growth. Journal of Political Economy, 116(3), 467-498. https://doi.org/10.1086/589523

Aghion, P., \& Howitt, P. (1998). Endogenous growth theory. Cambridge: MIT Press.

Aiginger, K. (2001). Speed of change and growth of manufacturing. In M. Peneder, K. Aiginger, \& M. Marterbauer (Eds.), Structural changes and economic growth (pp. 53-86). Vienna: Austrian Institute of Economic Research.

Arellano, M., \& Bond, S. (1991). Some tests of specification for panel data: Monte Carlo evidence and an application to employment equations. Review of Economic Studies, 58(2), 277-297. https://doi.org/10.2307/2297968

Arellano, M., \& Bover, O. (1995). Another look at the instrumental variable estimation of error-components models. Journal of Econometrics, 68(1), 29-51. https://doi.org/10.1016/0304-4076(94)01642-D

Ball, L., Jalles, J. T., \& Loungani, P. (2015). Do forecasters believe in Okun's Law? An assessment of unemployment and output forecasts. International Journal of Forecasting, 31(1), 176-184. https://doi.org/10.1016/j.ijforecast.2014.03.009

Baltagi, B. H. (2008). Econometric analysis of panel data. Chichester: Wiley. 
Baumol, W. J. (1967). Macroeconomics of unbalanced growth: the anatomy of urban crisis. American Economic Review, 57(3), 415-426.

Baumol, W. J., Blackman, S. A. B., \& Wolff, E. N. (1985). Unbalanced growth revisited: asymptotic stagnancy and new evidence. American Economic Review, 75(4), 806-817.

Beck, N., \& Katz, J. (2009). Modeling dynamics in time-series-cross-section political economy data. Annual Review of Political Science, 14, 331-352. https://doi.org/10.1146/annurev-polisci-071510-103222

Białowąs, T. (2016). Zmiany strukturalne a wzrost gospodarczy krajów Europy Środkowej. Rocznik Instytutu Europy Środkowo-Wschodniej, 14(5), 121-139 (in Polish).

Blundell, R., \& Bond, S. (1998). Initial conditions and moment restrictions in dynamic panel data models. Journal of Econometrics, 87(1), 115-143. https://doi.org/10.1016/S0304-4076(98)00009-8

Breitung, J. (2001). The local power of some unit root tests for panel data. In B. H. Baltagi, T. B. Fomby, \& R. C. Hill (Eds.), Nonstationary panels, panel cointegration, and dynamic panels advances in econometrics (pp. 161-177). Emerald Group Publishing Limited.

Bruno, G. S. F. (2005). Estimation and inference in dynamic unbalanced panel-data models with a small number of individuals. Stata Journal, 5(4), 473-500.

Caselli, F., \& Coleman, W. J. (2001). Cross-country technology diffusion: the case of computers. American Economic Review, 91(2), 328-335. https://doi.org/10.1257/aer.91.2.328

Chamberlain, G. (1984). Panel data. In Z. Griliches \& M. D. Intriligator (Eds.), Handbook of Econometrics, 2, 1247-1318.

Chenery, H. (1960). Patterns of industrial growth. American Economic Review, 50(4), 624-654.

Chenery, H. B., Robinson, S., \& Syrquin, M. (1986). Industrialization and growth: a comparative study. Washington DC: World Bank.

Choe, J. I. (2003). Do foreign direct investment and gross domestic investment promote economic growth? Review of Development Economics, 7(1), 44-57. https://doi.org/10.1111/1467-9361.00174

Clark, C. (1940). The conditions of economic progress. London: Macmillan.

Cortuk, O., \& Singh, N. (2010). Structural change and growth in India. Working Papers, UC Santa Cruz Economics Department 663.

Dietrich, A. (2012). Does growth cause structural change, or is it the other way around? A dynamic panel data analysis for seven OECD countries. Empirical Economics, 43(3), 915-944. https://doi.org/10.1007/s00181-011-0510-z

Dumitrescu, E., \& Hurlin, C. (2012). Testing for Granger non-causality in heterogeneous panels. Economic Modelling, 29(4), 1450-1460. https://doi.org/10.1016/j.econmod.2012.02.014

Echevarria, C. (1997). Changes in sectoral composition associated with economic growth. International Economic Review, 38(2), 431-452. https://doi.org/10.2307/2527382

Eichengreen, B., Park, D., \& Shin, K. (2012). When fast-growing economies slow down: international evidence and implications for China. Asian Economic Papers, 11(1), 42-87. https://doi.org/10.1162/ASEP_a_00118

Erdil, E., \& Yetkiner, I. H. (2009). The Granger-causality between health care expenditure and output: a panel data approach. Applied Economics, 41(4), 511-518. https://doi.org/10.1080/00036840601019083

Felipe, J., Kumar, U., \& Abdon, A. (2012). How rich countries became rich and why poor countries remain poor: it's the economic structure... duh! Working Paper No. 644. Annandale-on-Hudson, NY: Levy Economics Institute of Bard College.

Fisher, A. G. B. (1939). Production: primary, secondary and tertiary. Economic Record, 15(1), 24-38. https://doi.org/10.1111/j.1475-4932.1939.tb01015.x

Fourastié, J. (1949). Le grand espoir du XXe siècle. Progrès technique, progrès économique, progrès social. Paris: Presses Universitaires de France. 
Granger, C. W. J. (1969). Investigating causal relations by econometric models and cross-spectral methods. Econometrica, 37(3), 424-438. https://doi.org/10.2307/1912791

Grossmann, G., \& Helpman, H. (1991). Innovation and growth in the global economy. Cambridge: MIT Press.

Havlik, P. (2013). Structural change and economic growth in the new EU member states. GRINCOH Working Paper P1.4. Vienna Institute for International Economic Studies.

Holtz-Eakin, D., Newey, W., \& Rosen, H. (1985). Implementing causality tests with panel data, with an example from local public finance. NBER Technical Working Papers, No. 0048.

Hsiao, C. (1989). Modelling Ontario regional electricity system demand using a mixed fixed and random coefficients approach. Regional Science and Urban Economics, 19(4), 565-587. https://doi.org/10.1016/0166-0462(89)90020-3

Hurlin, C., \& Venet, B. (2001). Granger causality tests in panel data models with fixed coefficients. EURIsCO Université Paris Dauphine.

Hurlin, C. (2004). Testing Granger causality in heterogeneous panel data models with fixed coefficients. University Orléans.

Im, K. S., Pesaran, M. H., \& Shin, Y. (2003). Testing for unit roots in heterogeneous panels. Journal of Econometrics, 115(1), 53-74. https://doi.org/10.1016/S0304-4076(03)00092-7

Ishikawa, S. (1987). Structural change. In J. Eatwell, M. Milgate, \& P. Newman (Eds.), The new Palgrave: A dictionary of economics, 4, 523-525. https://doi.org/10.1057/978-1-349-95121-5_1775-1

Islam, N. (2001). Small sample performance of dynamic panel data estimators in estimating the growthconvergence equation: a Monte Carlo study. In B. H. Baltagi, T. B. Fomby, \& R. Carter Hill (Eds.), Nonstationary panels, panel cointegration, and dynamic panels (pp. 317-339). Emerald Group Publishing Limited.

Kiviet, J. F. (1995). On bias, inconsistency, and efficiency of various estimators in dynamic panel data models. Journal of Econometrics, 68(1), 53-78. https://doi.org/10.1016/0304-4076(94)01643-E

Kiviet, J. F. (1999). Expectation of expansions for estimators in a dynamic panel data model; some results for weakly exogenous regressors. In C. Hsiao, K. Lahiri, L.-F. Lee, \& M. H. Pesaran (Eds.), Analysis of panel data and limited dependent variables (pp. 199-225). Cambridge: Cambridge University Press. https://doi.org/10.1017/CBO9780511493140.010

Kongsamut, P., Rebelo, S., \& Xie, D. (2001). Beyond balanced growth. Review of Economic Studies, 68(4), 869-882. https://doi.org/10.1111/1467-937X.00193

Kuznets, S. (1959). On comparative study of economic structure and growth of nations. In R. W. Goldsmith (Ed.), The comparative study of economic growth and structure (pp. 162-176). National Bureau of Economic Research.

Laitner, J. (2000). Structural change and economic growth. Review of Economic Studies, 67(3), 545-561. https://doi.org/10.1111/1467-937X.00143

Lilien, D. M. (1982). Sectoral shifts and cyclical unemployment. Journal of Political Economy, 90(4), 777-793. https://doi.org/10.1086/261088

Lucas, R. (1988). On the mechanics of economic development. Journal of Monetary Economics, 22(1), 3-42. https://doi.org/10.1016/0304-3932(88)90168-7

Machlup, F. (1967). Essays in economic semantics. New York: W.W. Norton.

Mahmood, T., \& Linden, M. (2017). Structural change and economic growth in Schengen region. International Journal of Economics and Financial Issues, 7(1), 303-311.

Matsuyama, K. (2008). Structural change. In S. N. Durlauf, \& L. E. Blume (Eds.), The new Palgrave dictionary of economics ( $2^{\text {nd }}$ ed.) (pp. 136-153). London: Palgrave Macmillan.

https://doi.org/10.1057/978-1-349-95121-5_1775-2 
Moon, H. R., \& Perron, B. (2004). Testing for a unit root in panels with dynamic factors. Journal of Econometrics, 122(1), 81-126. https://doi.org/10.1016/j.jeconom.2003.10.020

Nair-Reichert, U., \& Weinhold, D. (2001). Causality tests for cross-country panels: a new look at FDI and economic growth in developing countries. Oxford Bulletin of Economics and Statistics, 63(2), 153-171. https://doi.org/10.1111/1468-0084.00214

Ngai, L. R., \& Pissarides, C. A. (2007). Structural change in a multisector model of growth. American Economic Review, 97(1), 429-443. https://doi.org/10.1257/aer.97.1.429

Nickell, S. (1981). Biases in dynamic models with fixed effects. Econometrica, 49(6), 1417-1426. https://doi.org/10.2307/1911408

Nurkse, R. (1953). Problems of capital formation in underdeveloped countries. Oxford: Basil Blackwell.

OECD. (2016). Promoting productivity and equality: a twin challenge. OECD Economic Outlook, 2016(1), 59-84. Retrieved from http://www.oecd-ilibrary.org/economics/oecd-economic-outlookvolume-2016-issue-1/promoting-productivity-and-equality-a-twin-challenge_eco_outlook-v20161-3-en/

Ohno, K. (2009). Avoiding the middle income trap: renovating industrial policy formulation in Vietnam. ASEAN Economic Bulletin, 26(1), 25-43. https://doi.org/10.1355/AE26-1C

Pasinetti, L. L. (1981). Structural change and economic growth: a theoretical essay on the dynamics of the wealth of nations. Cambridge: Cambridge University Press.

Pesaran, H. (2003). A simple panel unit root test in the presence of cross section dependence. Cambridge Working Papers in Economics 0346, Faculty of Economics, University of Cambridge. https://doi.org/10.2139/ssrn.457280

Pissarides, C. (1990). Equilibrium unemployment theory. Oxford: Basil Blackwell.

Raffinot, M., \& Venet, B. (2017). Low income countries, credit rationing and debt relief: bye bye international financial market? Retrieved from https://hal.archives-ouvertes.fr/hal-01489954/.

Romer, P. M. (1990). Endogenous technical changes. Journal of Political Economy, 98(5), 71-102. https://doi.org/10.1086/261725

Rosenstein-Rodan, P. N. (1943). Problems of industrialization of Eastern and South-Eastern Europe. Economic Journal, 53(210), 202-211. https://doi.org/10.2307/2226317

Schumpeter, J. (1934). Theory of economic development. Cambridge: Harvard University Press.

Semmler, W., Madrick, J., \& Khemraj, T. (2006). Okun's law and jobless growth. New York: Schwartz Center for Economic Policy Analysis. https://doi.org/10.13140/rg.2.1.4719.7522

Silva, E. G., \& Teixeira, A. C. (2008). Surveying structural change: seminal contributions and a bibliometric account. Structural Change and Economic Dynamics, 19(4), 273-300. https://doi.org/10.1016/j.strueco.2008.02.001

Solow, R. M. (1956). A contribution to the theory of economic growth. Quarterly Journal of Economics, 70(1), 65-94. https://doi.org/10.2307/1884513

Solow, R. M. (1957). Technical change and the aggregate production function. Review of Economics and Statistics, 39(3), 312-320.

Soylu, Ö. B., Çakmak, I., \& Okur, F. (2018). Economic growth and unemployment issue: Panel data analysis in Eastern European Countries. Journal of International Studies, 11(1), 93-107. https://doi.org/10.14254/2071-8330.2018/11-1/7

Stamer, M. (1998). Interrelation between subsidies, structural changes and economic growth in Germany: a vector autoregressive analysis. Konjunkturpolitik, 44(3), 231-253.

Stamer, M. (1999). Strukturwandel and wirtschaftliche Entwicklung in Deutschland, den USA and Japan. Aachen: Shaker. 
Syrquin, M. (2010). Kuznets and Pasinetti on the study of structural transformation: never the twain shall meet? Structural Change and Economic Dynamics, 21(4), 248-257.

https://doi.org/10.1016/j.strueco.2010.08.002

Timmer, M. P., Dietzenbacher, E., Los, B., Stehrer, R., \& de Vries, G. J. (2015). An illustrated user guide to the World Input-Output Database: the case of global automotive production. Review of International Economics, 23(3), 575-605. https://doi.org/10.1111/roie.12178

Weinhold, D. (1996). Investment, growth and causality testing in panels. Economie et Prévision, 126, 163-175.

Weinhold, D. (1999). A dynamic "fixed effects" model for heterogeneous panel data. London School of Economics.

Wheatley, A. (2010). Avoiding the middle income trap. New York Times, 25 October.

\section{APPENDIX}

\section{Appendix 1. Measures of structural changes (SCI, MLI) for GVA (right-hand axis) and employment (left-hand axis)}
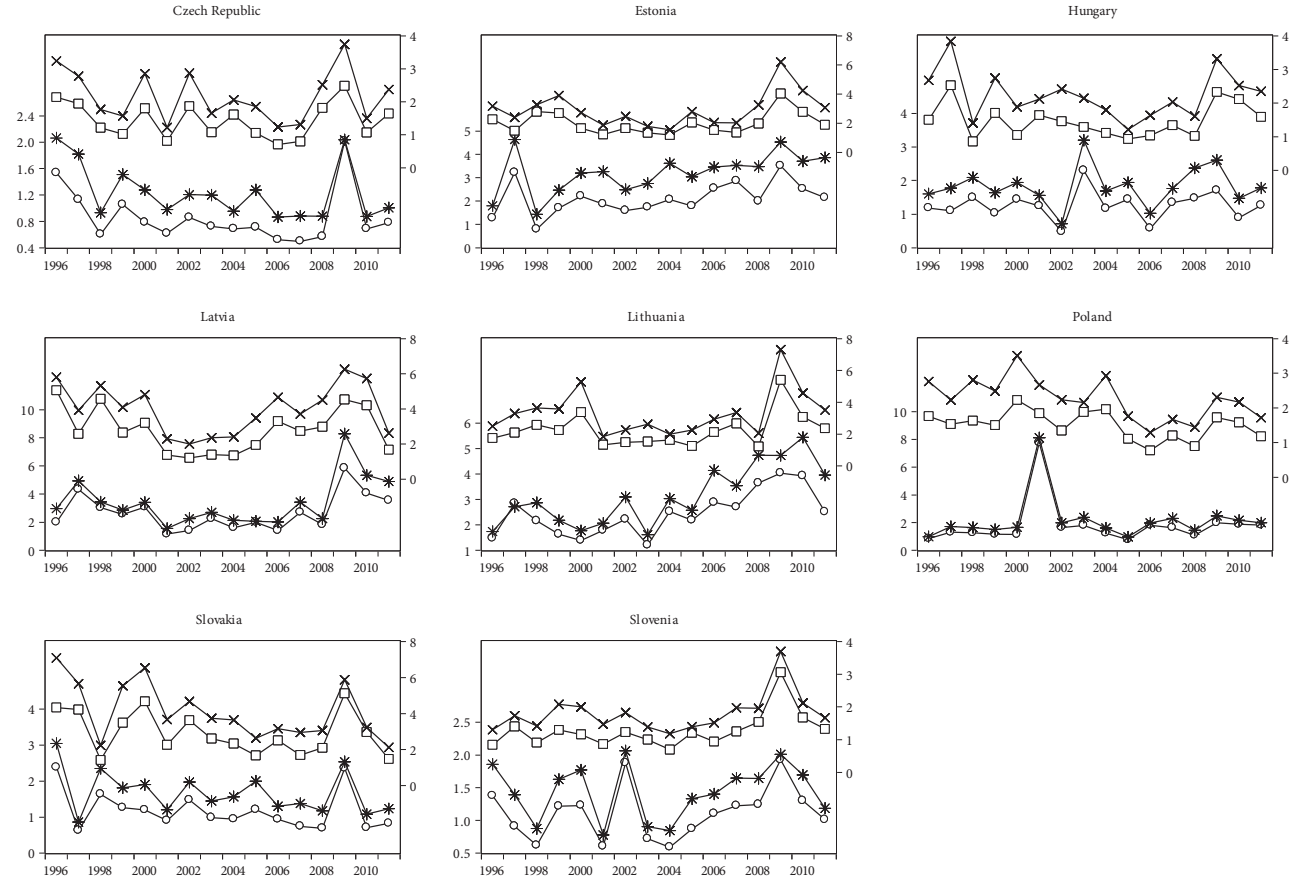

$$
\begin{array}{ll}
\underset{-0 \text { empMLI }}{\longrightarrow \text { vaMLI }} & \underset{*}{*} \text { empSCI } \\
\hdashline \text { vaSCI }
\end{array}
$$




\section{Appendix 2. GDP growth rate (left-hand axis) vs. structural changes in GVA and employment (right-hand axis)}
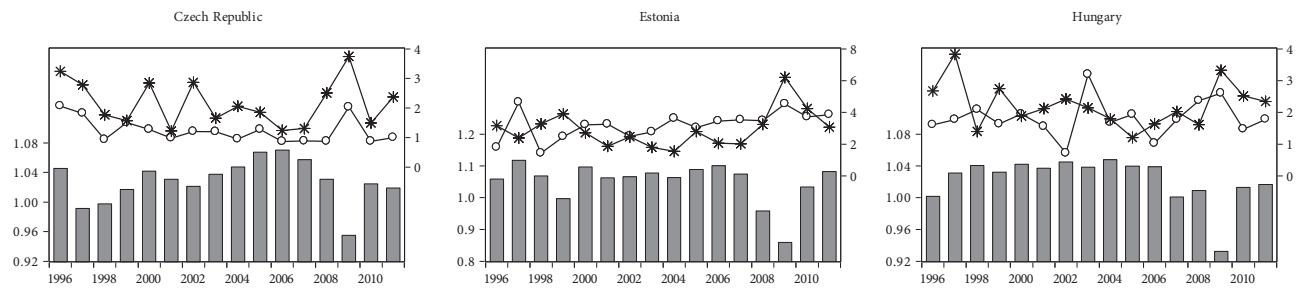

Latvia
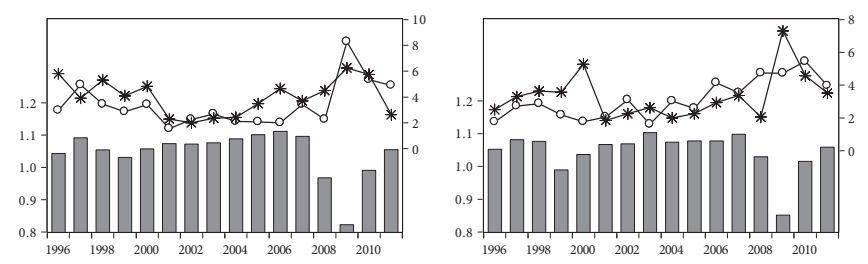

Slovakia
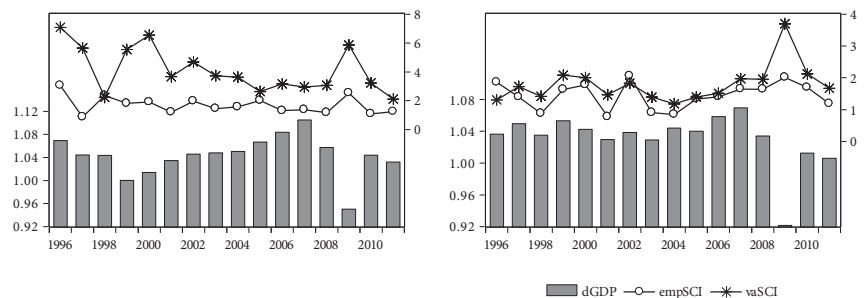

\section{Notations}

Variables and functions

$E M P$ - number of persons employed;

$G V A$ - gross value added;

$\triangle G D P$ - gross domestic product growth;

$\beta$ - slope coefficient;

$\gamma$ - autoregressive coefficient;

$i, j$ - countries;

$s, t$ - periods of time.

\section{Abbreviations}

CADF - cross-sectionally augmented Dickey-Fuller test;

GDP - gross domestic product;

GMM - generalized method of moments;

HC - homogeneous causality hypothesis;

HEN - heterogeneous non-causality hypothesis;

HNC - homogeneous non-causality hypothesis;

IPS - Im, Pesaran and Shin test;

LSDV - least squares dummy variables;

LSDVC - bias-corrected least squares dummy variables; 
MLI - modified Lilien index;

OECD - Organisation for Economic Co-operation and Development;

RMSE - root mean squared error;

RSS - residual sum of squares;

SCI - structural change index;

VAR - vector autoregressive model;

WIOD - World Input-Output Database. 